\title{
IN MEMORIAM: ACAD. PROF. YUCEL KANPOLAT, DISTINGUISHED AND INTERNATIONALLY RECOGNIZED NEUROSURGEON AND FRIEND OF THE REPUBLIC OF MACEDONIA
}

\begin{abstract}
The sad news about the death of Acad. Yucel Kanpolat (September 17, 2016), a famous scholar, a pioneer in the field of neurosurgery, and a friend of the Republic of Macedonia, saddened the members of the Editorial Board of the journal PRILOZI of the Department of Medical Sciences of the Macedonian Academy of Sciences and Arts, of which he was a member, as well as the other members of the Academy. Yucel Kanpolat was an international figure, linking Turkey to almost every country in the world. Neurosurgery has lost a very special surgeon, scientist and humanitarian. During the visit to the Macedonian Academy of Sciences and Arts in 2011, we discussed the cooperation between the Turkish Academy of Sciences and the Macedonian Academy of Sciences and Arts, which he respected very much, as well as the role of the academies. He delivered a lecture on The Mission of Academia in the Age of Science, PRILOZI, MASA, XXXII, 2, p. 7-10 (2011), which we reprint in addition.
\end{abstract}

Keywords: dead, neurosurgery, mission, science

The sad news about the death of Acad. Yucel Kanpolat (1941 - September 17, 2016), a renowned scientist, a pioneer in the field of neurosurgery, and a friend of the Republic of Macedonia, saddened the members of the Editorial Board of the journal PRILOZI -Contributions of the Department of Medical Sciences of the Macedonian Academy of Sciences and Arts, of which he was a member from 2012 to 2016, as well as the other members of the Academy. Yucel Kanpolat was an international figure, linking Turkey to almost every country in the world. Neurosurgery has lost a very special surgeon, scientist and humanitarian.

Dr. Kanpolat was born in Sivas, Turkey, and graduated from Gazi High School in Ankara in 1959. He attended Ankara University School of Medicine, obtaining his MD in 1965. He worked in the Turkish public health service from 1965 to 1968, and then went on to residency in the Department of Neurosurgery, Ankara University, from 1968 to 1973 . He served as Head of the Haydarpasa Military Neurosurgery Department, Istanbul, during his military service from 1974 to 1975, whereupon he was appointed Assistant Professor at the Department of Neurological Surgery, Ankara University, ascending to full professor in 1989.
His influence in functional and stereotactic neurosurgery, especially pain surgery, is renowned and will be lasting. He changed our thinking with regard to minimally invasive destructive procedures for pain, through his thorough knowledge of anatomy and physiology. He literally invented a minimally invasive image-driven ablative pain surgery-anterolateral cordotomy for somatic pain and trigeminal tractotomy / nucleotomy for facial pain. Many of us owe him a great debt for his teaching and clinical insights.

His scholarly achievement is notable, through 176 international publications, 92 invited lectures, 48 presentations in international congresses, and multiple visiting professorships and named lectures worldwide. He also served as president of the Turkish Academy of Sciences (TUBA) from 2008 to 2012. He was a member of the WFNS, ENS, WFFSN, EANS and a valued member of many journal editorial boards. He was a recipient of numerous awards including the Science Award of the Ankara University, the Turkish Neurosurgery Society Excellence Service Award (2006), the OHSU Paxton International Professorship (2006) and the Popular Bilim Medical Science Prize (2006). 
During his visit to Skopje, Republic of Macedonia we discussed the role of the academy in the development of society, education, the structure of the academies and the scientific cooperation between them. He greatly respected the Macedonian Academy of Sciences and Arts and he wanted a closer cooperation between MASA and the Turkish Academy of Sciences.

He delivered a lecture at the Macedonian Academy of Sciences and Arts on March 22, 2011 on the topic of The Mission of Academia in the Age of Science, published in the journal PRILOZI of MASA, XXXII, 2, p. 7-10 (2011). The ideas of Acad. Yucel Kanpolat are still contemporary, and therefore we are again printing the paper The Mission of Academia in the Age of Science in our journal PRILOZI.

As time passes, we see more and more the great loss of this respected friend of ours, but his work remains. 